\title{
PERBANDINGAN METODE REGRESI LINEAR DAN NEURAL NETWORK BACKPROPAGATION DALAM PREDIKSI NILAI UJIAN NASIONAL SISWA SMP MENGGUNAKAN SOFTWARE R
}

\author{
Masruroh $^{1}$, Kemal Farouq Mauladi ${ }^{2}$ \\ ${ }^{1,2)}$ Teknik Informatika, Fakultas Teknik, Universitas Islam Lamongan \\ Jl. Veteran No. 53A Lamongan \\ E-mail: masruroh@unisla.ac.id
}

\begin{abstract}
ABSTRAKS
Metode regresi linear dan neural network backpropagation merupakan metode yang kerap digunakan dalam model prediksi. Penelitian ini bertujuan untuk membandingkan akurasi metode regresi linear dan backpropagation dalam prediksi nilai Ujian Nasional siswa SMP. Data yang digunakan berupa data nilai ujian akhir semester dan ujian sekolah sebagai input dan nilai ujian nasional sebagai output. Data didapatkan dari SMPN 1 dan SMPN 2 Lamongan.. Jumlah dataset sebanyak 701 dibagi menjadi $75 \%$ data training dan 25\% data testing. Simulasi prediksi dilakukan menggunakan software R. Parameter akurasi yang digunakan adalah Root Mean Squared Error (RMSE) dan Mean Absolute Percentage Error (MAPE). Hasil penelitian menunjukkan model prediksi menggunakan metode regresi linear menghasilkan RMSE sebesar 9,04 dan MAPE sebesar 3,94\%, sedangkan model prediksi menggunakan backpropagation menghasilkan RMSE sebesar 7,28 dan MAPE sebesar 0,55\%. Dengan demikian dalam penelitian ini metode neural network backpropagation memiliki akurasi yang lebih baik dalam prediksi nilai Ujian Nasional siswa SMP.
\end{abstract}

Kata Kunci: Regresi Linear, Backpropagation, Prediksi, Nilai Ujian

\begin{abstract}
S
Linear regression and neural network backpropagation method is the common method that is used in the predictions model. This study attempts to compare the accuracy of linear regression and backpropagation method in the prediction of the national examination for junior high school students. Data was obtained from SMPN 1 and SMPN 2 Lamongan. The obtained data set as much as 701 data was divided into 75\% data as training set and $25 \%$ data as testing set. The simulation of national examination results prediction using the value of last semester examination and school examination as predictors is performed in $R$ software. The parameter of accuracy used in this research is Root Mean Squared Error (RMSE) and Mean Absolute Percentage Error (MAPE). The result showed linear regression method produce RMSE as much as 9,04 and MAPE 3,94\%, as much as regarding the predicted use backpropagation method that is produce RMSE as much as 7,28 and MAPE as much as 0,55\%. Thus, in this research the methods of neural network backpropagation having better accuracy than linear regression method in the prediction of the national examination for junior high school students.
\end{abstract}

Keywords: Linear Regression, Backpropagation, Prediction, Test Score

\section{PENDAHULUAN}

1.1 Latar Belakang

Ujian Nasional (UN) merupakan salah satu kegiatan pengukuran capaian kompetensi lulusan pada mata pelajaran tertentu secara nasional dengan mengacu pada Standar Kompetensi Lulusan. Mata Pelajaran yang diujikan dalam UN Sekolah Menengah Pertama (SMP) berdasarkan Prosedur Operasional Standar (POS) penyelenggaraan Ujian Nasional tahun 2017/2018 meliputi mata pelajaran Bahasa Indonesia, Matematika, Bahasa Inggris, dan Ilmu Pengetahuan Alam (BSNP, 2017).

Ujian Nasional memang tidak lagi menjadi penentu kelulusan siswa. Hal tersebut sesuai Peraturan Menteri Pendidikan dan Kebudayaan Republik Indonesia Nomor 4 Tahun 2018 tentang Penilaian Hasil Belajar oleh Pemerintah dan Penilaian Hasil Belajar oleh Satuan Pendidikan.
Meskipun demikian, hasil UN digunakan sebagai dasar untuk pemetaan mutu Satuan Pendidikan, pertimbangan seleksi masuk Jenjang Pendidikan selanjutnya, dan pembinaan serta pemberian bantuan kepada Satuan Pendidikan dalam upayanya untuk meningkatkan mutu pendidikan.

Dengan demikian, hasil UN tetap menjadi hal yang penting untuk diprediksikan. Hasil prediksi UN dapat dijadikan acuan bagi sekolah dalam proses pengambilan kebijakan yang terkait dengan peningkatan kualitas pendidikan kedepannya. Hasil prediksi UN juga dapat digunakan sebagai evaluasi awal siswa dalam persiapannya untuk menghadapi UN yang sebenarnya untuk mendapatkan hasil yang optimal nantinya.

Salah satu metode dapat digunakan untuk memprediksi nilai UN adalah metode regresi linear. Metode ini merupakan metode peramalan yang 
menggunakan garis lurus untuk menggambarkan hubungan antara dua variabel atau lebih (Disa, 2015). Metode ini sebelumnya telah digunakan oleh Farizal, Rachman, dan Rasyid (2014) dalam penelitiannya untuk memprediksi bahan bakar dengan hasil metode ini mampu menghasilkan akurasi sebesar 94,82\%. Penelitian serupa juga dilakukan oleh Nafi'iyah (2015) dengan hasil yang menunjukkan penggunaan metode regresi linear memberikan akurasi sebesar $80 \%$. Hasil penelitian Imtiyaz, Prasetio, dan Hidayat (2017) juga menunjukkan hal serupa dimana penggunaan metode regresi linear untuk prediksi menghasilkan akurasi sebesar 91,6\%. Sebagai tambahan, Susanto (2018) dalam penelitiannya juga menunjukkan penggunaan metode regresi linear untuk prediksi nilai ujian nasional mampu menghasilkan RMSE sebesar 0.5. Dengan demikian, dapat dikatakan bahwa penggunaan metode regresi linear dapat memberikan error yang relatif kecil pada hasil prediksi.

Selain metode regresi linear, metode yang dapat digunakan untuk prediksi adalah metode jaringan syaraf tiruan backpropagation. Metode ini adalah metode yang paling sering digunakan (Sihananto dan Mahmudy, 2016). Jaringan syaraf tiruan mengadopsi kemampuan otak manusia untuk memberikan rangsangan, memproses, dan memberikan keluaran (Pujianto, Kusrini, dan Sunyoto, 2017). Apriyani (2018) menyatakan bahwa kelebihan dari jaringan syaraf tiruan adalah kemampuan utamanya dalam prediksi dan menangkap hubungan yang sangat kompleks antara prediktor dan outputnya.

Penggunaan metode jaringan syaraf tiruan backpropagation dalam prediksi sebelumnya telah dilakukan oleh Lubis dan Buono (2012) dalam penelitiannya untuk memprediksi awal musim hujan dengan hasil RMSE terkecil sebesar 2.51. Hasil penelitian Kosasi (2014) juga menunjukkan bahwa penggunaan metode ini dapat memberikan nilai MSE terkecil sebesar 0.14. Penelitian serupa juga dilakukan oleh Utomo (2015) dengan hasil RMSE terkecil 0,169. Sihananto dan Mahmudy (2017) juga melakukan penelitian serupa dengan menghasilkan MSE terkecil 0,0168.

Sebagai tambahan, hasil penelitian Widodo, dkk (2017) menunjukkan bahwa penggunaan metode backpropagation dapat memberikan akurasi sebesar 95,93\%. Penelitian yang dilakukan oleh Pujianto, Kusrini, dan Sunyoto (2017) juga penelitian berbeda dengan metode yang sama yang dilakukan oleh Lesnussa, Sinay, dan Idah (2017) menghasilkan akurasi sebanyak 90\%. Dengan demikian, metode jaringan syaraf tiruan bacpropagation dapat menghasilkan RMSE yang relatif rendah dan akurasi yang tinngi.

Hasil penelitian yang dilakukan oleh Amrin (2017) menunjukkan bahwa penggunaan metode regresi linear lebih baik daripada metode backpropagation dalam prediksi dengan RMSE sebesar 0.0481 untuk regresi linear dan RMSE sebesar 0.0830 untuk metode backpropagation. Hasil penelitian Nafi'iyah (2016) menunjukkan bahwa penggunaan metode backpropagation lebih baik daripada metode regresi linear dengan akurasi sebesar $95 \%$ untuk metode backpropagation. dan 93\% untuk regresi linear.

Penelitian ini bertujuan untuk membandingkan akurasi metode regresi linear dan backpropagation dalam prediksi nilai Ujian Nasional siswa SMP menggunakan Root Mean Squared Error (RMSE) dan Mean Absolute Percentage Error (MAPE).

\subsection{Regresi Linear}

Regresi linear merupakan metode peramalan yang menggunakan garis lurus untuk menggambarkan hubungan antara dua variabel atau lebih (Disa, 2015). Regresi linear dengan satu variabel bebas disebut regresi linear sederhana sedangkan regresi linear dengan lebih dari satu variabel bebas disebut regresi linear berganda.

Hasil perhitungan regresi linear yang berupa persamaan nantinya dapat digunakan untuk memprediksikan nilai variabel terikat (Imtiyaz, Prasetio, dan Hidayat, 2017). Persamaan regresi linear yang digunakan dalam penelitian ini adalah sebagai berikut:

$\mathrm{Y}=\mathrm{a}+\mathrm{b}_{1} \mathrm{X}_{1}+\mathrm{b}_{2} \mathrm{X}_{2}+\mathrm{b}_{3} \mathrm{X}_{3}+\ldots+\mathrm{b}_{7} \mathrm{X}_{7}$

Dengan:

$\mathrm{Y}=$ Nilai Ujian Nasional

$\mathrm{X}_{1}=$ Nilai Ujian Akhir Semester 1

$\mathrm{X}_{2}=$ Nilai Ujian Akhir Semester 2

$\mathrm{X}_{3}=$ Nilai Ujian Akhir Semester 3

$\mathrm{X}_{4}=$ Nilai Ujian Akhir Semester 4

$\mathrm{X}_{5}=$ Nilai Ujian Akhir Semester 5

$\mathrm{X}_{6}=$ Nilai Ujian Akhir Semester 6

$\mathrm{X}_{7}=$ Nilai Ujian Akhir Sekolah

$\mathrm{a}=$ konstanta

$\mathrm{b}_{1}, \ldots, \mathrm{b}_{7}=$ Gradien

\subsection{Jaringan Syaraf Tiruan Backpropagation}

Jaringan syaraf tiruan mengadopsi kemampuan otak manusia untuk memberikan rangsangan, memproses, dan memberikan keluaran (Pujianto, Kusrini, dan Sunyoto, 2017). Algoritma dari model ini terdiri atas sejumlah jaringan syaraf tiruan yang saling terhubung antara satu dengan yang lainnya (Sihananto dan Mahmudy, 2017).

Penyusun dari jaringan syaraf tiruan biasanya terdiri atas tiga lapisan, yaitu lapisan input, lapisan tersembunyi, dan lapisan output (Lesnussa, Sinay, dan Idah, 2017). Lapisan input terdiri atas unit-unit input yang menerima pola data dari luar, lapisan tersembunyi (hidden layer) berisi unit-unit yang outputnya tidak bisa langsung diamati, dan lapisan output yang terdiri atas unit-unit output yang 
merupakan solusi yang dihasilkan dari jaringan syaraf tiruan.

Menurut Lesnussa, Latuconsina, dan Parsulessy, 2015) jaringan syaraf tiruan memiliki beberapa arsitektur yang biasa diterapkan dalam aplikasi, diantaranya adalah jaringan lapisan tunggal (single layer network), jaringan banyak lapisan (multilayer network), dan jaringan lapisan kompetitif (competitive layer network). Arsitektur jaringan syaraf tiruan yang paling sering digunakan adalah jaringan banyak lapisan (multilayer network) dengan kombinasi pembelajaran backpropagation (Sihananto dan Mahmudy, 2016). Arsitektur yang digunakan dalam penelitian ini secara umum dapat dilihat pada Gambar 1.

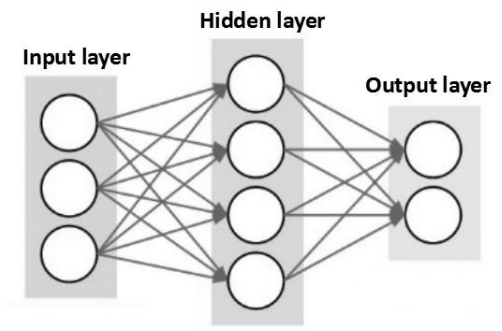

\section{Gambar 1. Arsitektur jaringan syaraf tiruan multilayer network}

Kelebihan dari metode backpropagation adalah metode ini mampu memformulasikan pengalaman dan pengetahuan peramal serta fleksibel dalam perubahan peraturan perkiraan (Mataram, dalam Widodo, dkk, 2017). Selain itu jaringan syaraf tiruan juga memili toleransi yang tinggi terhadap data yang mengandung noise dan mampu menagkap hubungan yang sangat kompleks antara variabel prediktor (input ) dengan outputnya (Apriyani, 2018). Meskipun demikian metode ini juga memiliki beberapa kekurangan, diantaranya adalah hasil pelatihan yang tidak konstan dan tidak diketahui secara detail bagaimana hasil prediksi tersebut diperoleh (Widodo, dkk, 2017). Hal tersebut dikarenakan tidak ada model struktural yang jelas yang dihasilkan oleh metode ini (Apriyani, 2018). Selain itu Apriyani (2018) menambahkan bahwa jaringan syaraf tiruan bisa menghasilkan prediksi yang invalid bila input yang diterima diluar range yang diberikan saat pelatihan atau data training yang dibutuhkan tidak cukup.

\section{METODE}

Penelitian ini dilakukan dengan menggunakan data nilai Ujian Akhir Sekolah (UAS), nilai Ujian Sekolah (US), dan nilai Ujian Nasional (UN) siswa angkatan 2015 yang lulus tahun 2018. Data yang digunakan sebagai input adalah data nilai Ujian Akhir Sekolah (UAS)dan nilai Ujian Sekolah (US), sedangkan outputnya adalah dan nilai Ujian Nasional (UN). Proses simulasi prediksi dilakukan menggunakan software R.
Data diambil dari SMPN 1 Lamongan dan SMPN 2 Lamongan menggunakan metode dokumentasi. Dataset yang terkumpul sebanyak 701 data siswa. Sebanyak $75 \%$ dataset dijadikan sebagai data training dan $25 \%$ sisanya dijadikan sebagai data testing.

Proses analisis data dilakukan dengan melakukan training pada masing-masing metode yang digunakan yaitu metode regresi linear dan backpropagation menggunakan data training. Dari hasil training dengan metode regresi linear akan didapatkan persamaan regresi linear, sedangkan dari metode backpropagation akan didapatkan arsitektur jaringan syaraf tiruan. Dalam penelitian ini spesifikasi jaringan syaraf tiruan yang digunakan adalah jaringan syaraf tiruan dengan jumlah input sebanyak tujuh, jumlah unit lapisan tersembunyi sebanyak tujuh unit, dan satu output.

Persamaan regresi linear dan arsitektur jaringan syaraf yang telah dilatih pada tahap training akan diuji coba menggunkan data testing sehingga didapatkan nilai akurasinya menggunakan Root Mean Squared Error (RMSE) dan Mean Absolute Percentage Error (MAPE). RMSE dan MAPE dihitung menggunakan rumus berikut:

$$
\begin{aligned}
& \text { RMSE }=\sqrt{\frac{\sum\left|D_{t}-F_{t}\right|^{2}}{n}} \\
& M A P E=\frac{\sum \mid D_{t}-F_{t} / / D_{t}}{n} \\
& \text { Dengan: } \\
& \mathrm{D}_{\mathrm{t}}=\text { data aktual } \\
& \mathrm{F}_{\mathrm{t}} \quad=\text { nilai prediksi } \\
& \mathrm{n} \quad=\text { jumlah data }
\end{aligned}
$$

Tahapan dalam proses penelitian ini dapat dilihat pada Gambar 2.

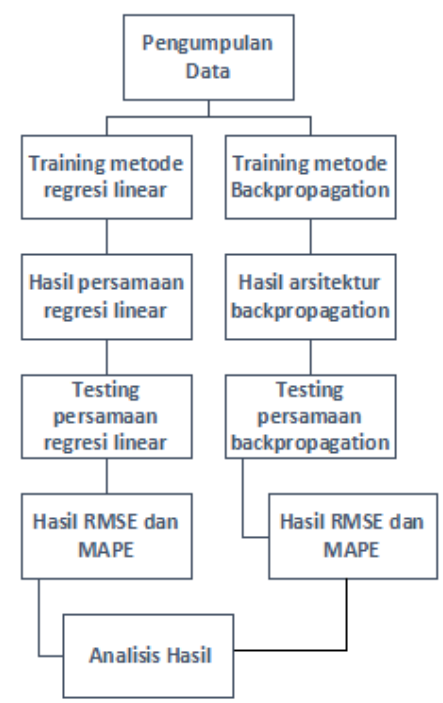

Gambar 2. Tahapan proses penelitian 


\section{PEMBAHASAN}

\subsection{Metode Regresi Linear}

Hasil analisis data training dengan metode regresi linear berganda untuk tiap mata pelajaran dapat dilihat pada Tabel 1.

Tabel 1. Hasil analisis regresi linear

\begin{tabular}{|c|c|c|}
\hline Keterangan & RMSE & MAPE \\
\hline Bahasa Indonesia & 7,75 & $1,87 \%$ \\
\hline Matematika & 10,63 & $8,06 \%$ \\
\hline IPA & 8,66 & $2,15 \%$ \\
\hline Bahasa Inggris & 9,10 & $3,69 \%$ \\
\hline Rata-rata & $\mathbf{9 , 0 4}$ & $\mathbf{3 , 9 4 \%}$ \\
\hline
\end{tabular}

Berdasarkan Tabel 1. dapat dilihat bahwa model persamaan regresi linear yang didapatkan untuk mata pelajaran Bahasa Indonesia dengan nilai residual standard error sebesar 6,92 adalah:

$\mathrm{Y}=-97,46+0,07 \mathrm{X}_{1}+0,32 \mathrm{X}_{2}+0,28 \mathrm{X}_{3}+1,09 \mathrm{X}_{4}$ $+0,39 \mathrm{X}_{5}-0,64 \mathrm{X}_{6}+0,53 \mathrm{X}_{7}$

Model persamaan regresi linear yang didapatkan untuk mata pelajaran Matematika dengan nilai residual standard error sebesar 9,56 adalah:

$\mathrm{Y}=-75,28+0,24 \mathrm{X}_{1}+0,39 \mathrm{X}_{2}+0,60 \mathrm{X}_{3}+0,66 \mathrm{X}_{4}$ $0,004 X_{5}-0,26 X_{6}+0,17 X_{7}$

Model persamaan regresi linear yang didapatkan untuk mata pelajaran IPA dengan nilai residual standard error sebesar 8,41 adalah:

$\mathrm{Y}=-60,07+0,16 \mathrm{X}_{1}+0,09 \mathrm{X}_{2}+0,13 \mathrm{X}_{3}+0,71 \mathrm{X}_{4}$ $+0,64 \mathrm{X}_{5}-0,67 \mathrm{X}_{6}+0,53 \mathrm{X}_{7}$

Model persamaan regresi linear yang didapatkan untuk mata pelajaran Bahasa Inggris dengan nilai residual standard error sebesar 8,70 adalah:

$\mathrm{Y}=-56,74+0,50 \mathrm{X}_{1}+0,67 \mathrm{X}_{2}+0,02 \mathrm{X}_{3+} 0,05 \mathrm{X}_{4}+0,67 \mathrm{X}_{5}$ $-0,21 \mathrm{X}_{6}-0,14 \mathrm{X}_{7}$

Model persamaan yang didapatkan dari tiap mata pelajaran yang diujikan tersebut kemudian digunakan untuk simulasi prediksi nilai UN menggunakan data testing. Simulasi dilakukan untuk mendapatkan akurasi dari tiap model persamaan ketika diterapkan pada data testing. Hasil akurasi simulasi prediksi nilai UN dapat dilihat pada Tabel 2.

Tabel 2. Akurasi dari hasil penerapan persamaan regresi linear

\begin{tabular}{|c|c|c|c|c|}
\hline $\begin{array}{c}\text { Mata } \\
\text { Pelajaran }\end{array}$ & BIN & MTK & IPA & BIG \\
\hline a & $-97,46$ & $-75,28$ & $-60,07$ & $-56,74$ \\
\hline b1 & 0,07 & 0,24 & 0,16 & 0,50 \\
\hline b2 & 0,32 & 0,39 & 0,09 & 0,67 \\
\hline b3 & 0,28 & 0,60 & 0,13 & 0,02 \\
\hline b4 & 1,09 & 0,66 & 0,71 & 0,04 \\
\hline b5 & 0,39 & $-0,004$ & 0,64 & 0,67 \\
\hline b6 & $-0,64$ & $-0,26$ & $-0,67$ & $-0,21$ \\
\hline b7 & 0,53 & 0,17 & 0,53 & $-0,14$ \\
\hline $\begin{array}{c}\text { Residual } \\
\text { SE }\end{array}$ & $\mathbf{6 , 9 2}$ & $\mathbf{9 , 5 6}$ & $\mathbf{8 , 4 1}$ & $\mathbf{8 , 7 0}$ \\
\hline
\end{tabular}

Berdasarkan Tabel 2 dapat diketahui bahwa dari penerapan persamaan regresi linear pada data testing didapatkan rata-rata RMSE sebesar 9,04 dan MAPE sebesar 3,94\%.

\subsection{Metode Neural Network Backpropagation}

Hasil analisis data training dengan metode neural network Backpropagation untuk tiap mata pelajaran berupa plot arsitektur jaringan dapat dilihat pada Gambar 3 sampai Gambar 6. Arsitektur jaringan yang digunakan dalam penelitian iniadalah jaringan dengan jumlah input sebanyak tujuh, jumlah unit lapisan tersembunyi sebanyak tujuh unit, dan satu output.

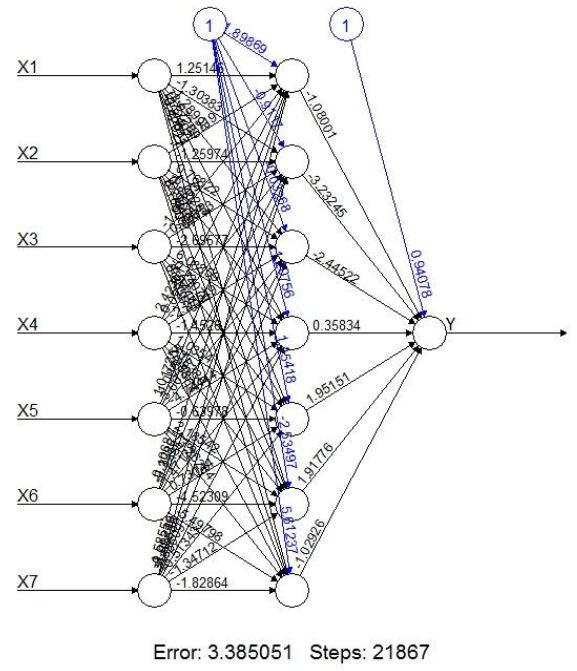

Gambar 3. Plot arsitektur neural network untuk mata pelajaran Bahasa Indonesia

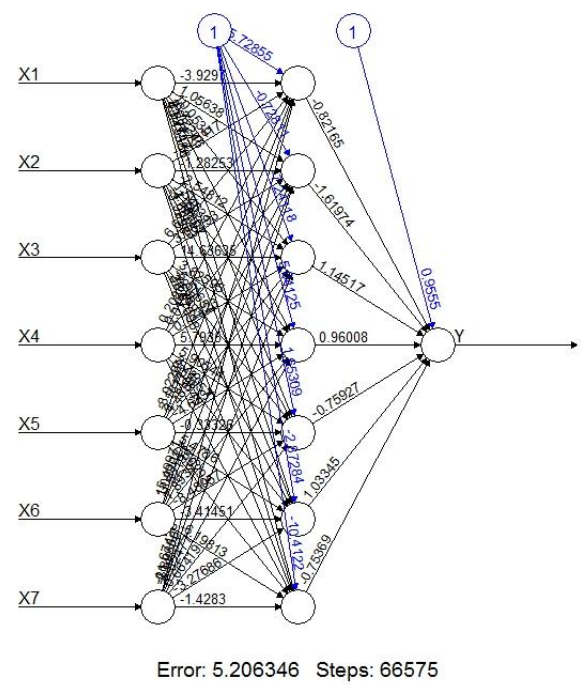

Gambar 4. Plot arsitektur neural network untuk mata pelajaran Matematika 


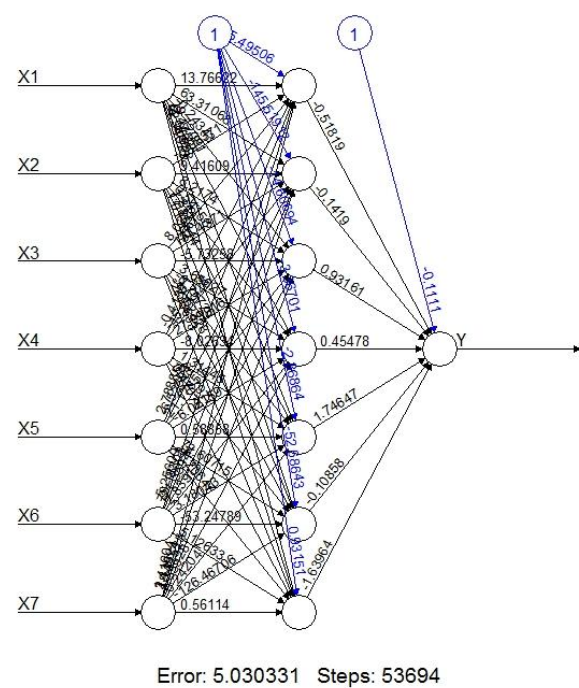

Gambar 4. Plot arsitektur neural network untuk mata pelajaran IPA

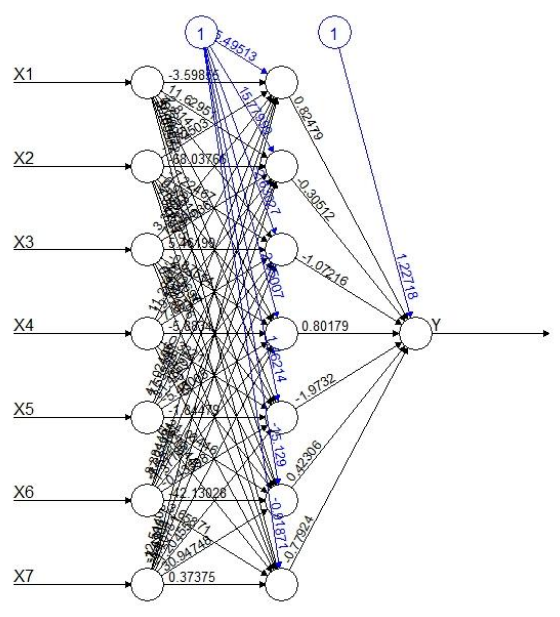

Error: 3.967543 Steps: 48729

Gambar 4. Plot arsitektur neural network untuk mata pelajaran Bahasa Inggris

Berdasarkan Gambar 4 sampai Gambar 6 dapat diketahui nilai error yang dihasilkan tiap arsitektur jaringan untuk tiap mata pelajaran. Rekap nilai error yang dihasilkan tiap arsitektur jaringan dapat dilihat pada Tabel 3.

Tabel 3. Nilai error tiap arsitektur jaringan

\begin{tabular}{|c|c|c|c|c|}
\hline $\begin{array}{c}\text { Mata } \\
\text { Pelajaran }\end{array}$ & BIN & MTK & IPA & BIG \\
\hline Error & 3,385 & 5,06 & 5,030 & 3,968 \\
\hline $\begin{array}{c}\text { Rata-rata } \\
\text { Error }\end{array}$ & \multicolumn{4}{|c|}{$\mathbf{4 , 3 9 7}$} \\
\hline
\end{tabular}

Berdasarkan Tabel 3. dapat diketahui error yang dihasilkan arsitektur jaringan untuk mata pelajaran Bahasa Indonesia sebesar 3,385, Matematika sebesar 5,06, IPA sebesar 5,030, dan Bahasa Inggris sebesar 3,968. Rata-rata error yang dihasilkan arsitektur jaringan sebesar 4,397.
Arsitektur jaringan dari tiap mata pelajaran tersebut kemudian diterapkan pada data testing untuk mendapatkan nilai akurasi menggunakan RMSE dan MAPE. Akurasi dari hasil penerapan arsitektur jaringan tersebut dapat dilihat pada Tabel 4.

Tabel 4. Akurasi dari hasil penerapan arsitektur jaringan

\begin{tabular}{|c|c|c|}
\hline Keterangan & RMSE & MAPE \\
\hline Bahasa Indonesia & 7,19 & $0,11 \%$ \\
\hline Matematika & 9,93 & $0,64 \%$ \\
\hline IPA & 9,48 & $0,03 \%$ \\
\hline Bahasa Inggris & 2,51 & $1,42 \%$ \\
\hline Rata-rata & $\mathbf{7 , 2 8}$ & $\mathbf{0 , 5 5 \%}$ \\
\hline
\end{tabular}

Berdasarkan Tabel 4 dapat diketahui bahwa dari penerapan metode neural network backpropagation pada data testing didapatkan rata-rata RMSE sebesar 7,28 dan MAPE sebesar 0,55\%.

Perbandingan akurasi yang dihasilkan dari penerapan tiap metode dapat dilihat pada Tabel 5.

Tabel 5. Perbandingan akurasi penerapan tiap metode

\begin{tabular}{|c|c|c|c|c|}
\hline \multirow{2}{*}{$\begin{array}{c}\text { Keterang } \\
\text {-an }\end{array}$} & \multicolumn{2}{|c|}{ Reresi Linear } & \multicolumn{2}{c|}{ Backpropagation } \\
\cline { 2 - 5 } BIN & RMSE & MAPE & RMSE & MAPE \\
\hline MTK & 10,75 & $1,87 \%$ & 7,19 & $0,11 \%$ \\
\hline IPA & 8,66 & $8,06 \%$ & 9,93 & $0,64 \%$ \\
\hline BIG & 9,10 & $3,69 \%$ & 9,48 & $0,03 \%$ \\
\hline Rata-rata & $\mathbf{9 , 0 4}$ & $\mathbf{3 , 9 4 \%}$ & $\mathbf{7 , 2 8}$ & $\mathbf{0 , 5 5 \%}$ \\
\hline
\end{tabular}

Dari Tabel 5 dapat diketahui bahwa dari penerapan persamaan regresi linear pada data testing didapatkan rata-rata RMSE sebesar 9,04 dan MAPE sebesar 3,94\% sedangkan dari penerapan neural network backpropagation didapatkan rata-rata RMSE sebesar 7,28 dan MAPE sebesar 0,55\%. Dengan demikian dapat dikatakan bahwa dalam penelitian ini metode neural network backpropagation memiliki akurasi yang lebih baik dalam prediksi nilai Ujian Nasional siswa SMP. Hal ini sesuai dengan hasil penelitain yang dilakukan oleh Nafi'iyah (2016) yang menunjukkan bahwa penggunaan metode backpropagation lebih baik daripada metode regresi linear untuk prediksi.

\section{KESIMPULAN}

Berdasarkan analisis hasil penelitian dapat disimpulkan bahwa:

a. Penerapan persamaan regresi linear menghasilkan rata-rata RMSE sebesar 9,04 dan MAPE sebesar $3,94 \%$.

b. Penerapan neural network backpropagation menghasilkan rata-rata RMSE sebesar 7,28 dan MAPE sebesar 0,55\%. 
c. Metode neural network backpropagation memiliki akurasi yang lebih baik dalam prediksi nilai Ujian Nasional siswa SMP

\section{UCAPAN TERIMAKASIH}

1. Terimakasih kepada DRPM Ristekdikti yang telah mendanai penelitian ini

2. Terimakasih kepada SMPN 1 dan SMPN 2 Lamongan atas kerjasamanya dalam proses pengambilan data.

\section{PUSTAKA}

Amrin. 2016. AnalisaKomparasi Neural Network Backpropagation dan Multiple Linear Regression untuk Peramalan Tingkat Inflasi. Jurnal teknik Komputer AMIK Bekasi. Vol. 2 No. 2: 1-6.

Apriyani, Yanti, 2018. Penerapan Jaringan Syaraf Tiruan Backpropagation untuk Prediksi Nilai UN Siswa SMPN 2 Cihaurbeuti. Indonesian Journal on Computer and Information Technology (IJCIT). Vol. 3 No. 1: 63-70.

Badan Standar Nasional Pendidikan. 2017. Prosedur Operasional Standar Penyelenggaraan Ujian Nasional. Jakarta: Badan Standar Nasional pendidikan (BSNP)

Disa, S. 2015. Penerapan Metode Regresi Linear dalam Pembuatan Perangkat Lunak Simulasi Target Penjualan. Jurnal Inspiration, Vol. 5 No. 2: 82-89.

Farizal, F., Rachman, A., \& Rasyid, H. A. 2014. Model Peramalan Konsumsi Bahan Bakar Jenis Premium Di Indonesia Dengan Regresi Linier Berganda. Jurnal Ilmiah Teknik Industri. Vol.13 No. 2: 166-176.

Imtiyaz, H., B. H., Prasetio, dan N. Hidayat. 2017. Sistem Pendukung Keputusan Budidaya Tanaman Cabai Berdasarkan Prediksi Curah Hujan. Jurnal Pengembangan Teknologi Informasi dan Ilmu Komputer. Vol.1 No. 9: 733-738.

Kosasi, Sandy, 2014. Penerapan Metode Jaringan Syaraf Tiruan Backpropagation untuk Memprediksi Nilai Ujian Sekolah.. Researchgate [online] tersedia di:<https://www.researchgate.net/publication/32 2165269_Penerapan_Metode_Jaringan_Saraf_Ti ruan_Backpropagation_untuk_Memprediksi_Nil ai_Ujian_Sekolah> [ diakses 10 Maret 2019].

Lesnussa, Y. A., L. J., Sinay, dan E. R., Persulessy, 2015. Aplikasi Jaringan Saraf Tiruan Backpropagation untuk Memprediksi Prestasi Siswa SMA (Studi Kasus: Prediksi Prestasi Siswa SMAN 4 Ambon. Jurnal Matematika Integratif(JMI). Vol. 11 No. 2: 149-160.

Lesnussa, Y. A., L. J., Sinay, dan M. R., Idah, 2017. Aplikasi Jaringan Saraf Tiruan Backpropagation untuk Penyebaran Penyakit Demam Berdarah Dengue (DBD) di Kota Ambon. Jurnal
Matematika Integratif(JMI). Vol. 13 No. 2: 6372.

Lubis, L. S., Agus Buono, 2012. Artificial Neural Network Modeling To Predict The Beginning of Rainy Season Based On Sea Surface Temperature. Jurnal Ilmu Komputer \& AgriInformatika. Vol. 1 No. 2: 52-61.

Nafi'iyah, Nur. 2016. Perbandingan Regresi Linear, Backpropagation, dan Fuzzy Mamdani dalam Prediksi Harga Emas. Prosiding Seminar Nasional Inovasi dan Aplikasi Teknologi di Industri (SENIATI), Institut Teknologi Nasional Malang, Jawa Timur, Malang, 6 Februari.

Nafiiyah, N. 2015. Penerapan Regresi Linear dalam Memprediksi Harga Jual Mobil Bekas. Prosiding Seminar Nasional Pengembangan Aktual Teknologi Informasi (SENA BAKTI), R.2.7-1 -R.2.7-6, Universitas Pembangunan Nasional "Veteran ", Jawa Timur, Surabaya, 5 Desember.

Pujianto, A., Kusrini, A., Sunyoto, 2018. Perancangan Sistem Pendukung Keputusan untuk Prediksi Penerima Beasiswa Menggunakan Metode Neural Network Backpropagation. Jurnal Teknologi Informasi dan Ilmu Komputer (JTIIK). Vol. 5 No. 2: 157-162.

Sihananto, A., N. dan W. F., Mahmudy. 2017. Rainfall Forecasting Using Backpropagation Neural Network. Jurnal of Information Technology and Computer Science. Vol. 2 No. 2: 66-76.

Susanto, Tri. P. 2018. Prediksi Nilai Unas SMP 1 Berbek Menggunakan Metode Regresi Linear Sederhana. Simki-Techsain. Vol. 6 No. 2: 1-9.

Utomo, Winarto, 2015. Prediksi Nilai Ujian Nasional Produktif Sekolah Menengah Kejuruan Menggunakan Metode Neural Network. Techno.COM. Vol. 14 No. 1: 33-41.

Widodo, A.P., Suhartono, E. A., Sarwoko, dan Z. Firdaus, 2017. Akurasi Model Prediksi Metode Backpropagation Menggunakan Kombinasi Hidden Neuron dengan Alpha. Jurnal Matematika. Vol. 20 No. 2: 79-84. 